\title{
PENGARUH MODAL INTELEKTUAL TERHADAP EARNING PER SHARE PADA INDUSTRI DASAR DAN KIMIA PERIODE 2012-2016
}

\author{
R. Achmad Drajat Aji \\ Fakultas Bisnis dan Manajemen Universitas Widyatama \\ ahmad.drajat@widyatama.ac.id \\ Ajeng Andriani Hapsari \\ Fakultas Bisnis dan Manajemen Universitas Widyatama \\ ajeng.andriani@widyatama.ac.id
}

\begin{abstract}
This research aims to examine the effect of intellectual capital on Earning Per Share (EPS) especially on the company operating in the basic and chemical industries. This study used purposive sampling method to collect secondary data sourced from Indonesia Stock Exchange (IDX) in the period of 2012-2016. The population was all companies operating in basic and chemical industries that listed in IDX for the period of 2012-2016, with the sample consisted of 58 companies. Data were analyzed by multiple linear regression. The results showed that Value Added Capital Employed (VACA) had a significant effect on EPS, meaning that the proper use of the capital would increase company value that would finally increase its EPS. Value Added Human Capital (VAHU) also had a significant effect on EPS, meaning that the company's good human resources management would create added value to increase profit that would ultimately increase EPS. However, Structural Capital Value Added (STVA) had no significant effect on EPS, meaning that the company had not achieved competitive advantage due to less optimal management of structural capital and EPS.
\end{abstract}

Keywords: Intellectual Capital, VAHU, STVA, VACA, and EPS.

\begin{abstract}
Abstrak: Penelitian ini bertujuan untuk menguji pengaruh dari modal intelektual terhadap Earning Per Share (EPS). khususnya pada perusahaan yang bergerak dalam industri dasar dan kimia. Data sekunder bersumber dari Bursa Efek Indonesia (BEI) yang diambil berdasarkan teknik purposive sampling. Sampel penelitian terdiri dari 58 perusahaan yang bergerak dalam industri dasar dan kimia yang terdaftar di BEI periode 2012-2016. Metode analisis data yang digunakan adalah regresi linear berganda. Hasil penelitian menunjukkan adanya pengaruh signifikan Value Added Capital Employed (VACA) terhadap EPS yang berarti bahwa penggunaan modal secara tepat akan menaikan nilai perusahaan untuk meningkatkan nilai keuntungan per lembar sahamnya. Value Added Human Capital (VAHU) mempengaruhi EPS, yang mengindikasikan bahwa pengelolaan sumber daya perusahaan yang baik berdampak pada terciptanya nilai tambah bagi perusahaan untuk meningkatkan laba yang nantinya mampu menambah jumlah EPS. Namun, variabel Structural Capital Value Added (STVA) tidak berpengaruh terhadap EPS yang mengindikasikan bahwa keunggulan bersaing perusahaan belum dapat tercapai karena pengelolaan structural capital dan EPS yang belum optimal.
\end{abstract}

Kata Kunci: Modal Intelektual, VAHU, STVA, VACA, dan EPS. 


\section{Pendahuluan}

Dalam roda ekonomi Indonesia, pasar modal memeran peranan penting. Pasar modal (capital market), menarik investor sebagai pemberi dana dapat berinvestasi pada bermacam sekuritas dengan tujuan mendapat return. Pasar modal (capital market) menjadi media bertransaksi instrumen keuangan jangka panjang, seperti utang, ekuitas (saham), instrumen derivatif, dan instrumen lainnya (Darmadji dan Fakhrudin, 2012:1). Pasar modal merupakan tempat bertransaksi saham (sekuritas) perusahaan dan penyajian informasi perihal kondisi kinerja harga saham perusahaan di pasar modal yang terlihat dari perusahaan tersebut. Tinggi atau rendahnya harga saham dapat terlihat juga dari kinerja perusahaan.

Pada tahun 2015 -2016 sektor industri dasar dan kimia menunjukkan adanya penurunan harga saham yang terkait dengan kondisi ekonomi. Perusahaan INTP $3,61 \%$, SMGR 1,18\%, dan SMCB 2,62\%, yaitu perusahaan sektor industri dan kimia mengalami penurunan harga saham pada tahun 2015. Pada tahun 2016 di sektor industri dan dasar kimia ini mengalami peningkatan dalam sepekan dan hanya bertahan secara jangka pendek, dilihat dari penurunan laba bersih dampak dari kondisi kelebihan pasokan atas penjualan semen di Indonesia. Hal tersebut terlihat dari salah satu emiten semen yakni PT Semen Indonesia Tbk (SMGR), PT Indocement Tungggal Prakarsa Tbk (INTP) dan PT Semen Baturaja Tbk (SMBR) Informasi yang diperoleh dari Bursa Efek Indonesia mengenai kinerja indeks harga saham (stock prices indices) pada Indeks Industri Dasar dan Kimia adalah sebagai berikut :

Tabel 1. Data Kinerja Indeks Saham Periode 2011-2016

\begin{tabular}{ccc}
\hline Tahun & Kinerja Indeks Saham & Persentase \\
\hline 2013 & 2.184 & $21,60 \%$ \\
2014 & 2.144 & $-1,83 \%$ \\
2015 & 1.675 & $-21,88 \%$ \\
2016 & 1.307 & $-21,97 \%$ \\
\hline
\end{tabular}

Sumber: Data diolah, 2018

Penurunan kinerja indeks saham Industri Dasar dan Kimia dapat terlihat dari rasio pertumbuhan kinerja indeks saham dari tabel di atas. Pada tahun 2013-2016 Industri Dasar dan Kimia mengalami penurunan kinerja indeks saham. Tabel di atas juga menunjukkan bahwa industri dasar dan kimia belum maksimal dalam meningkatkan kinerja indeks saham perusahaan. Perusahaan yang tergolong pada industri tersebut harus mampu bersaing demi meraih tujuan perusahaan. 
Pada dasarnya semua perusahaan mempunyai tujuan yang serupa yakni mengoptimalkan kemakmuran para pemegang sahamnya yang salah satunya dapat dilihat pada Earning Per Share (EPS). Laba perlembar saham atau Earning Per Share itu adalah indikator kemampuan perusahaan untuk mendapatkan keuntungan per lembar saham pemilik. Oleh karena itu, maksimalisasi nilai EPS seharusnya menjadi dasar dalam mencapai tujuan perusahaan (Utami dan Hidayah, 2017)

Aset pengetahuan (knowledge asset) pada saat ini sudah dijadikan mesin baru perusahaan untuk meningkatkan penggerak utama dalam pengembangan bisnis. Sebagai aset tak berwujud perusahaan mengakui modal intelektual dan bersifat abstrak tersebut hal utama penggerak perusahaan (Fajriani,2017). Pada saat ini kenyataannya hal tersebut masih belum bisa dibuktikan di indonesia, intellectual capital masih kurang. Human capital, structural capital, dan customer capital di Indonesia jumlahnya sedikit, masih banyak perusahaan di Indonesia yang enggan untuk memfokuskan perhartian kepada intellectual capital. Saat ini banyak kasus di indonesia yang cendrung menggunakan conventional based oleh sebab itu masih miskin teknologi yaang dihasilkan (Kuryanto dan Muchamad, 2008). Fakta sebenarmya perusahaan lebih mampu bersaing jika memiliki dan mengaplikasikan keunggulan kompetitif. Keunggulan kompetitif tersebut didapat dari intellectual capital yang terlihat di laporan keuangan yang dihasilkan dari inovasi. Secara tidak langsung berdampak pertambahan nilai perusahaan dengan keunggulan bersaing dibandingkan perusahaan yang tidak menampilkan intellectual capital dalam laporan keuangannya.

Penelitian terdahulu oleh Indrajaya, 2015; Yaputra dan Prasetyo, 2012; Rona, 2013; Salim dan Golrida, (2013) mengenai pengaruh modal intelektual terhadap Earning Per Share menghasilkan kesimpulan bahwa modal intelektual berpengaruh terhadap nilai perusahaan, keuangan perusahaan dipengaruhi oleh modal intelektual. Terdapat hubungan dari tiga komponen intellectual capital dengan kedua indikator kinerja keuangan yakni ROE dan EPS. Sedangkan hasil penelitian Rona, 2013 variabel dependen tidak signifikan memiliki pengaruh pada earning per share (EPS) dan terhadap variabel indevenden VAIC.

\section{Metodologi}

Penelitian ini bertujuan untuk menguji pengaruh Intellectual capital yang terdiri dari Capital Employed, Human Capital, dan Structural Capital terhadap Earning Per Share (EPS). Metodologi penelitian yang digunakan dalam penelitian ini adalah 
verifikatif. Metode verifikatif adalah suatu metode untuk menguji kausalitas antar variabel melalui uji hipotesis dengan perhitungan statistik sehingga dihasilkan bukti yang menyatakan hipotesis ditolak atau diterima (Nazir,2011:91).

Berdasarkan judul penelitian tersebut, dalam penelitian ini terdapat satu variabel bebas yaitu Intellectual Capital dengan dimensi variabel VACA (Value Added Capital Employeed), VAHU (Value Added Human Capital) dan STVA (Value Added Structural Capita). Variabel terikat dalam penelitian ini adalah Earning Per Share. Penelitian ini menganalisa perusahaan yang terdaftar di Bursa Efek Indonesia dari unit sektor industri dasar dan kimia periode 2012-2016.

\section{Populasi dan Sampel}

Dalam penelitian ini yang menjadi populasi adalah 69 (enam puluh Sembilan) perusahaan yang terdaftar di Bursa Efek Indonesia periode 2012-2016 dari perusahaan sektor Industri Dasar dan Kimia. Tehnik sampling pada penlitian ini menggunakan non probability sampling dan metode purposive sampling, yaitu sampling dengan mengambil populasi sebagai sampel. Purposive sampling adalah teknik sampling dengan pertimbangan tertentu (Sugiyono, 2017:124). Pemilihan sampel secara purposive sampling dilakukan dengan berdasarkan kriteria yang ditentukan dengan tujuan untuk mendapat sampel yang mewakili. Berdasarkan kriteria pengambilan sampel tersebut, perusahaan yang menjadi sampel dari penelitian ini adalah perusahaan yang terdaftar di Bursa Efek Indonesia periode 20122016 sebanyak 58 (lima puluh delapan) perusahaan pada Industri Dasar dan Kimia.

\section{Operasionalisasi Variabel}

Operasional variabel adalah definisi variabel secara konsep, praktik dan nyata dalam lingkup objek yang diteliti, sementara definisi variabel adalah suatu nilai dari sifat atau objek yang mempunyai nilai untuk dipelajari dan diambil kesimpulan (Sugiyono, 2017). Sesuai dengan judul penelitian ini "Pengaruh Intellectual Capital Terhadap Earning Per Share", variabel yang terdiri atas variabel independen Intellectual Capital yang diukur dengan VACA (Value Added Capital Employeed), VAHU (Value Added Human Capita), dan STVA (Value Added Structural Capital), sedangkan variabel dependen yaitu Earning Per Share (EPS) itulah variabel dalam penelitian ini. 


\section{Variabel Independen}

Variabel Independen $(X)$ dalam penelitiaan ini yang digunakan adalah Intellectual Capital yang dihitung dengan menggunakan ketiga dimensi VAIC ${ }^{\mathrm{TM}}$. Tahapan perhitungan $\mathrm{VAIC}^{\mathrm{TM}}$ adalah sebagai berikut :

a. Value Added Capital Employed (VACA)

VA yang diciptakan oleh satu unit dari capital employed. Rasio yang dibuat oleh setiap unit dari CE terhadap value added perusahaan menunjukkan kontribusi.

$$
V A C A=\frac{\text { Value Added }}{\text { Capital Employed }}
$$

Dimana :

Ouput (OUT) = = Total penjualan dan pendapatan lain

Input $(\mathrm{IN}) \quad$ = Beban dan biaya-biaya (selain karyawan)

VA = Selisih antara Output dan Input

Capital Employed (CE) = Dana yang tersedia (ekuitas, laba bersih)

\section{b. Value Added Human Capital (VAHU)}

VA dapat diperoleh dari dana yang diperuntukan untuk tenaga kerja. Dalam human capital $(\mathrm{HC})$ rasio ini menujukan kontribusi yang dibuat oleh setiap rupiah yang diinvestasikan terhadap value added perusahaan.

$$
V A H U=\frac{\text { Value Added }}{\text { Human Capital }}
$$

Dimana:

Ouput (OUT) = Total penjualan dan pendapatan lain

Input (IN) = Beban dan biaya-biaya (selain karyawan)

VA $\quad=$ Selisih antara Output dan Input

Human Capital( $\mathrm{HC})$ = Beban karyawan

\section{c. Structural Capital Value Added (STVA)}

Rasio yang mengukur jumlah SC yang dibutuhkan untuk menghasilkan 1 rupiah dari VA dan merupakan indikatopr SC dalam keberhasilan penciptaan nilai.

$$
S T V A=\frac{\text { Value Added }}{\text { Structural Capital }}
$$

Dimana :

Ouput (OUT) = = Total penjualan dan pendapatan lain 
Input $(\mathrm{IN})=$ Beban dan biaya-biaya (selain karyawan)

VA

$=$ Selisih dari Output dan Input

Structural Capital (SC) $\quad=$ VA-HC

Variabel Dependen

Variabel dependen $(\mathrm{Y})$ pada penelitian ini adalah Earning Per Share. Variabel dependen yang dijelaskan adalah tipe yang dipengaruhi oleh variabel independen. Perhitungan Earning Per Share dengan menggunakan:

$$
\text { EPS }=\frac{\text { EAT }}{\text { Jumlah Lembar Saham }} \times 100 \%
$$

\section{Metode Analisis Data}

Untuk menguji analisis dilakukan pengujian secara verikatif untuk mengetahui apakah Intellectual Capital mempengaruhi Earning Per Share. Dalam menganalisis data menggunakan program SPSS 20 sebagai alat bantuan untuk menguji model yang telah dirumuskan.

\section{Hasil dan Pembahasan}

\section{Analisis Korelasi dan Koefisiensi Determinasi}

Pengujian koefisien determinasi $\left(\mathrm{R}^{2}\right)$ berfungsi untuk mengukur kemampuaan seberapa jauh model dalam menerangkan variable - variabel dependen Ghozali (2013:197).

Tabel 2. Hasil Uji Koefisisen Determinasi

\begin{tabular}{|c|c|c|c|}
\hline Model & $\mathbf{R}$ & R Square & $\begin{array}{l}\text { Adjusted R } \\
\text { Square }\end{array}$ \\
\hline 1 & $0,600^{\mathrm{a}}$ & 0,36 & 0,349 \\
\hline
\end{tabular}

Pada tabel 2 menunjukkan bahwa hasil dari koefisien determinasi sebesar 0,36 atau $36,00 \%$. Hal ini menunjukkan bahwa dimensi variabel Intellectual Capital berpengaruh sebesar $36,00 \%$ terhadap Earning Per Share (EPS). Sedangkan sebanyak $100 \%-36,00 \%=64,00 \%$ oleh variabel lain dijelaskan yang tidak diteliti dalam penelitian ini. 
Hasil Regresi dan Pengujian Hipotesis

Tabel 3. Hasil Analisis Regresi

\begin{tabular}{cccc}
\hline Model & B & $\mathbf{t}$ & Sig. \\
\hline (Constant) & $-0,794$ & $-4,448$ & 0,000 \\
VACA & 1,03 & 7,801 &, 000 \\
VAHU & 1,190 & 2,786 &, 006 \\
STVA & $-0,111$ & $-0,841$ &, 402
\end{tabular}

Dependent Variable: EPS

Sumber : diolah

Dari tabel di atas, didapat persamaan regresi linier berganda sebagai berikut: $Y=-0,794+1,03 X_{1}+1,190 X_{2}-0,667 X_{3}$

Berdasarkan persamaan varibel di atas dapat diinterpretasikan masingmasing variabel sebagai berikut:

1. Angka konstanta sebesar $-0,794$ pada persamaan di atas menunjukkan bahwa jika perusahaan tidak memiliki VACA, VAHU, dan STVA, maka besarnya rata-rata EPS akan bernilai -0,794.

2. Value Added Capital Employed (VACA) mempunyai nilai koefisien sebesar 1,03. Hal tersebut menggambarkan bahwa ketika Capital Employed meningkat satu satuan akan meningkatkan EPS sebesar 1,03.

3. Value Added Human Capital (VAHU) mempunyai nilai koefisien sebesar 1,190. Hal tersebut menggambarkan bahwa ketika Human Capital meningkat satu satuan akan meningkatkan EPS sebesar 1,190.

4. Structural Capital Value Added (STVA) memiliki nilai koefisien sebesar -0,111. Hal tersebut menggambarkan bahwa ketika Structure Capital meningkat $1 \%$ akan menurunkan EPS sebesar 0,111.

Tabel 4. Hasil Uji F

\begin{tabular}{ccc}
\hline Model & F & Signifikansi \\
\hline Regression & 33,381 &, 000
\end{tabular}

Sumber: diolah

$\underline{\text { Hasil Uji F }}$

Berdasarkan hasil, didapat nilai signifikansi pada tabel 4 model regresi secara simultan sebesar 0,000, nilai ini lebih kecil dari significance leve/0,05 atau 0,000<0,05. Dengan demikian dapat disimpulkan bahwa variable-variabel Value Added Capital Employed (VACA), Value Added Human Capital (VAHU) dan Structural Capital Value Added (STVA) berpengaruh terhadap Earning Per Share (EPS). 


\section{$\underline{\text { Hasil Uji t }}$}

Berdasarkan tabel 5, akan ditunjukan hasil pengujian parsial dari komponenkomponen Intellectual Capital Value Added Capital Employed (VACA), Value Added Human Capital (VAHU), dan Structural Capital Value Added (STVA) terhadap Earning Per Share (EPS).

Dengan dilakukan pengujiaan ini menggunakan significance level $0.05(\alpha=$ $5 \%$ ). Penolakan atau penerimaan pada uji parsial dilakukan bila $t$ hitung $>t$ tabel atau probabilitas < tingkat signifikansi (Sig $<0.05)$, maka Ho ditolak dan Ha diterima artinya variabel independen berpengaruh terhadap variabel dependen. Bila $t$ hitung $<t$ tabel atau probabilitas $>$ tingkat signifikansi $(\mathrm{Sig}>0.05)$, maka Ho diterima dan Ha ditolak artinya variabel independen tidak berpengaruh terhadap variabel dependen.

Tabel 5. Hasil Uji Analisis Parsial (uji t)

\begin{tabular}{ccc}
\hline Variabel Independen & $\mathbf{t}$ & Signifikansi \\
\hline VACA & $-7,801$ &, 000 \\
VAHU & 2,786 &, 006 \\
STVA & $-0,841$ &, 402 \\
\hline
\end{tabular}

Sumber: diolah

Pengaruh Value Added Capital Employed Terhadap Earning Per Share (EPS)

Berdasarkan hasil di atas dapat dilihat bahwa untuk variable VACA, $\mathrm{H}_{0}$ ditolak dan Ha diterima karena tingkat signifikansi Value Added Capital Employed (VACA) sebesar $0,000<0,05$. Dapat disimpulkan bahwa variabel Value Added Capital Employed (VACA) berpengaruh terhadap Earning Per Share (EPS). Hasil penelitian ini sejalan dengan hasil Muthaher dan Iwan (2014) yang menyatakan bahwa VACA berpengaruh terhadap EPS. Hal ini menunjukkan bahwa perusahaan pertambangan merupakan perusahaan yang sahamnya diperdagangkan dalam volume yang tinggi dan para investor menangkap informasi pengunaan capital employed tersebut. Penggunaan modal secara tepat menghasilkan nilai tambah bagi perusahaan untuk meningkatkan nilai laba per lembar sahamnya.

Pengaruh Value Added Added Human Capital Terhadap Earning Per Share $\underline{(E P S)}$

Berdasarkan hasil pada tabel 5 di atas juga dapat dilihat bahwa keputusan variable VAHU adalah $\mathrm{H}_{0}$ ditolak dan Ha diterima karena tingkat signifikansi Value Added Human Capital (VAHU) sebesar 0,006 < 0,05. Dapat disimpulkan bahwa variabel Value Added Human Capital (VAHU) berdampak pada Earning Per Share (EPS). Penelitiaan ini sejalan dengan hasil Muthaher dan Iwan (2014) yang 
menyebutkan hasil penelitiannya bahwa Value Added Human Capital (VAHU) berdampak pada EPS. Dengan hal tersebut perusahan dapat menunjukkan bahwa perusahaan telah mampu mengelola sumber daya yang dimiliki perusahaan akan dapat nilai tambah untuk meningkatkan profit yang akhirnya dapat meningkatkan Earning Per Share.

\section{Pengaruh Structural Capital Value Added Terhadap Earning Per Share (EPS)}

Sementara untuk variable STVA karena mempunyai nilai signifikansi di atas 0.05 maka $\mathrm{H}_{0}$ diterima dan Ha ditolak karena tingkat signifikansi Structural Capital Value Added (STVA) sebesar 0,402 >0,05. Dengan demikian dapat disimpulkan bahwa variabel Structural Capital Value Added (STVA) tidak berpengaruh terhadap Earning Per Share (EPS). Hasil penelitian ini sejalan dengan Muthaher dan Iwan (2014) yang juga menyimpulkan bahwa perusahaan belum mampu mengelola structural capital yang dimiliki untuk mencapai keunggulan bersaing guna menghasilkan Earning Per Share yang lebih tinggi.

\section{Kesimpulan}

Pembahasan yang telah dilakukan berdasarkan berdasarkan hasil data maka penelitian ini pengambil keismpulan bahwa Value Added Capital Employed (VACA) berpengaruh terhadap Earning Per Share (EPS). Value Added Human Capital (VAHU) berpengaruh terhadap EPS dan Earning Per Share. Structural Capital Value Added (STVA) tidak memberikan pengaruh pada Earning Per Share (EPS).

\section{Saran}

Dalam penelitian ini, beberapa saran yang dapat dijadikan pertimbangan ini bagi para peneliti selanjutnya agar mendapatkan hasil yang lebih baik. (1) Bagi para peneliti selanjutnya sebaiknya memperdalam materi dan menambah periode penelitian. Dengan memperdalam materi dan menambah periode penelitian dapat memberikan gambaran yang diharapkan lebih terhadap penelitian variabel intellectual capital; (2) Memilih area yang lebih luas atau area lainnya yang lebih besar karena dengan pemilihan sektor yang lebih besar yang nantinya diharapkan akan mendapatkan hasil yang jauh lebih akurat. 


\section{Daftar Referensi}

Darmadji, T. dan Fakhruddin H.M. 2012. Pasar Modal Indonesia: Pendekatan Tanya Jawab. Edisi Ketiga. Jakarta : Salemba Empat.

Fajriani, Puteri Dena. 2017. Pengaruh Intellectual Capital Terhadap Nilai Perusahaan. Skripsi. (Tidak Dipublikasikan). Program Studi Manajemen. Universitas Widyatama, Bandung.

Indrajaya, Andrean. 2015. Pengaruh modal intelektual terhadap Nilai Perusahaan. Skripsi. Program Studi Akuntansi. Universitas Sanata Dharma. Yogyakarta.

Kuryanto, Benny dan Muchamad Syafrudin, (2008). Pengaruh Modal Intelektual Terhadap Kinerja Perusahaan. Makalah Disampaikan dalam Simposium Nasional Akuntansi XI. Pontianak: 23-24 Juli

Muthaher, Osmad dan Iwan Nur Prasetyo. 2014. Pengaruh modal intelektual terhadap ROE dan EPS Sebagai Proksi Kinerja Keuangan. EKOBIS Vol. 15 No.2.

Nazir, Mohammad. 2011. Metode Penelitian. Jakarta : Ghalia Indonesia.

Rona, Dea Nikki. 2013. Pengaruh Modal Intelektual Terhadap Kinerja Keuangan Pada Perusahaan Manufaktur di Bursa Efek Indonesia Tahun 2007-2011. Skripsi. Sekolah Tinggi llmu Ekonomi Perbanas. Surabaya.

Salim, Selvi M dan Golrida Karyawati, (2013), Pengaruh Modal Intelektual Terhadap Kinerja Keuangan. Journal of Business and Entrepreneurship. ISSN: 2302 - 4119 Vol. 1, No. 2.

Sugiyono. 2017. Metode Penelitian Kuantitatif, Kualitatif, dan R\&D. Bandung : Alfabeta.

Utami, Eristy Minda dan Riski Taufik Hidayah. 2017. The Influence of Capital Structure On Earning Per Share. JRMSI Vol.8 No.2

Yaputra, Andreas dan Ari Hadi Prasetyo. 2012. Pengaruh Modal Intelektual Terhadap Kinerja Keuangan Perusahaan Infrastruktur, Utilitas, dan Transportasi yang Terdaftar di Bursa Efek Indonesia Periode 2008-2010. Vol. 1 No.1

http://digilib.mercubuana.ac.id/manager/t!@file_artikel_abstrak/lsi_Artikel_3791650951 20.pdf 